\title{
What Determines the Technological Capabilities of the Agribusiness Sector in Mexico?
}

\author{
Alejandra López-Salazar ${ }^{1}$, Celina López-Mateo ${ }^{1}$ \& Rubén Molina-Sánchez ${ }^{1}$ \\ ${ }^{1}$ Department of Finance and Administration, University of Guanajuato, Guanajuato, México \\ Correspondence: Alejandra López-Salazar, Department of Finance and Administration, University of Guanajuato, \\ Celaya, Guanajuato, México. Tel: 52-462-598-5922 ext. 1662. E-mail: alelopez.salazar@yahoo.com
}

Received: August 12, 2014

Accepted: August 26, 2014

Online Published: September 25, 2014

doi:10.5539/ibr.v7n10p47

URL: http://dx.doi.org/10.5539/ibr.v7n10p47

\begin{abstract}
Technological capabilities are of great importance for the social and economic development of a country, especially in developing countries such as Mexico, and in strategic sectors like agribusiness. Seventy-one companies from the manufacturing sector of the agri-food industry in the Laja-Bajío region are studied in order to analyze the internal factors that encourage the development of technological capabilities. A model is proposed to analyze the variables that influence technological capacity, such as, cultural capital, social capital, information technologies, investment in $R \& D$, age and size. The results show that social capital, investment in R\&D, age and size are variables that help explain the level of technological capability. This has implications for academia, business, and the government.
\end{abstract}

Keywords: technological capabilities, agribusiness sector, resource-based view

\section{Introduction}

Studies on technological capabilities are extremely relevant, not only to industrialized countries but also to developing ones. This is due to the fact that the environment is forcing companies to develop skills that allow them to implement technological changes in order to stay competitive. The pressure to improve products and services (especially from international competition), the macroeconomic environment, and the availability of ever more efficient and complex technologies are some of the factors that influence the development of technological capabilities (Lall, 1992).

Contrary to the traditionalist approach, which minimizes the importance of technological development in developing countries, this study is based on evolutionary theories because: a) they emphasize on learning in order to generate technical change; b) there are differences between the capabilities of companies to assimilate the technologies and to generate technological changes; c) differences exist not only at the macro-level, but also between sectors and companies (Lugones, Gutti \& Le Clech, 2007; Bell \& Pavitt, 1995; Dosi, 1988). Evolutionary theories state that "technological knowledge is not shared equally among firms, nor is it easily imitated by or transferred across firms. Transfer necessarily requires learning because technologies are tacit, and their underlying principles are not always clearly understood" (Lall, 1992; p. 166). The simple viewpoint considers that the acquisition and accumulation of capital goods and knowing how to operate that technology has limited studies on technological capacities in these countries, especially in certain sectors.

The development of technological capabilities is a fundamental pillar for the economic and social development of a country, because it raise productivity levels, quality, and efficiency in the use of resources, generating improvements in products and processes, expansion into new markets with more value-added products and services, all of which enhance the competitive edge of the organization. However, companies face a series of obstacles before they may improve their technological capabilities; firstly, they must possess a mixture of resources and skills in order to generate technical change, which are not easy to acquire, transfer nor share (Lall, 1992), and secondly, because technological development implies an economic risk for the companies and the investment may not lead to the planned benefits (Whitfield, 2012) and may in fact incur hidden costs (costs that are unlikely to be recovered), which may be a disincentive for innovation.

Due to the fact that companies in developing countries do not have the same level of maturity in their technological capabilities as their counterparts in industrialized countries, they obtain greater performance 
despite having the same technology because they have reached high levels of efficiency in their operations, functions and routines (Lall, 1992). As such, the technological capabilities of a company should be analyzed with a distinct focus to that assumed in developed countries. Technological capabilities should be analyzed based on a more ad hoc assessment, depending on the context and the industry to which it belongs.

Accordingly, the objective of this study is to analyze the internal factors that encourage the processes of technological capability development in agri-food companies. The analysis was undertaken at the microeconomic level, based on resource-based view of the firm, without neglecting the environmental (Note 1) factors that influence the development of technological capabilities.

The current research is centered on the agri-food industry due to the great importance that it has for the economy of the Laja-Bajío region of the State of Guanajuato and for the difficulties that have presented themselves in order to compete internationally. According to the latest census data, the agri-food industry in the Laja-Bajío region generates $40 \%$ of jobs, over $30 \%$ of the production, and more than $50 \%$ of the inversion in the state (INEGI, 2009). Even though the agri-food industry has grown in the last ten years, the number of companies has decreased, and small businesses have not survived new market conditions, increasing the inequality between subsectors of the industry (Martín \& Estrada, 2011).

Another reason to focus this study on the agri-food industry is the lack of studies on underdeveloped countries that analyze the technological capabilities of the sector. Dutrénit, Vera-Cruz and Arias (2003) mention that little attention has been placed on analyzing the factors that stimulate the process of technological capacity development and that we do not yet understand the differences in technological capacities per industrial sector. In light of this issue, it is necessary to find the elements that may ignite the development of technological abilities of the agri-food sector.

This paper is organized into four sections. The first section is an introduction to the issue and the objective of the study. The second section offers the theoretical foundation of technological capabilities and the hypotheses are stated. Subsequently, the methodology and measurement of variables are presented. The results and discussion are shown in the fourth and fifth sections respectively. The paper ends with conclusions drawn from the results.

\section{Theoretical Background}

\subsection{Resource Based View of the Firms}

The Resource Based View of the Firm sustains that companies must base their strategies on the resources and capabilities they possess because they are unique and heterogeneous among companies, and because they are the basis of sustained competitive advantage (Barney, 1991). Consequently, it is the endowment of resources and capabilities that explains differences in business results (Rumelt, 1984). Resources are defined as "stocks of available factors that are owned or controlled by the firm" and capabilities are the "firm's capacity to deploy resources, usually in combination, using organizational processes, to effect a desired end" (Amit \& Shoemaker, 1993:35). Capabilities are understood as the set of organizational routines and complex patterns of interaction between people and resources (Grant, 1991) that establish the guidelines for task development, for which there is a dynamic component in capabilities and also the static component of resources. Not all resources and capabilities have the potential to generate competitive advantage. Only those resources and capabilities that are valuable, rare, difficult to imitate and difficult to substitute are the source of competitive advantage (Barney, 1991).

According to Hitt and Ireland (2000), capabilities are generally developed through the transmission and interchange of information and knowledge between the personnel of the company, resulting in collective learning in the organization (Prahalad \& Hamel, 1990). In this sense, "the ability to use knowledge to develop new products, services and processes... is essential to the development of technological capabilities" (Zahra, Neubaum \& Larrañeta, 2007:1070). Due to the fact that technological knowledge isn't easy to imitate, transfer, or share among companies (Lall, 1992) is considered a strategic resource with the potential to develop sustained competitive advantage (Barney, 1991), on condition that mechanisms are established to acquire it, spread awareness of it, and codify it (Zahra et al., 2007). The level of technological knowledge will be determined by the set of abilities, skills, and experience that the company possesses, combined with industry and market factors (Lall, 1992).

\subsection{Technological Capabilities}

Diverse definitions have been used to describe technological capabilities. Kim (1997; p. 86) conceptualizes technological capacities as "the ability to make an effective use of technological knowledge in efforts to assimilate, use, adapt and change the existing technologies, which may result in development of technology and 
development of new products and process in response to changing economic environment". Hobday and Rush (2007; p. 1341) define it as "the accumulated knowledge, skill experience and organizational base which enable a firm to acquire, develop and use technology to achieve competitive advantage".

These definitions state the special importance of the use of knowledge as a central element of technological capability. The differences in the accumulated body of knowledge of the company, the way in which they use knowledge and the ways they increase it are fundamental aspects for the accumulation of technological capabilities. As such, the development of technological capabilities implies the existence of abilities and knowledge that cannot be explained, recognized or easily (tacitly) transmitted, which implies a process of learning that requires a conscious effort (Whitfield, 2012). Nonaka and Takeuchi (1995, cited in Mendes \& DuBois, 2012) comment that tacit knowledge should be transformed into explicit knowledge through conversation mechanisms, evidenced in routines, procedures, manuals, among others.

Learning takes place through three processes; the first, is the acquisition of knowledge from internal or external sources; the second, is the socialization of knowledge, and the third is the codification of that knowledge. This implies that individual learning is turned into organizational learning, and that this learning process is what allows technological capability to accumulate (Figueiredo, 2003).

Other authors focus more generally on the abilities and resources necessary to develop innovative processes and products. Such is the case of Figueiredo $(2002 ;$ p. 74) who defines technological capabilities as "resources needed to generate and manage improvement in processes and production organization, products, equipment and engineering projects". Morrison, Pietrobelli, and Rabelloti (2007 cited in Cuero, Un Nabi \& Dornberger, 2012) considered that technological capabilities do not only comprise of technical skills, but also directive, and organizational skills.

Technological Capability in this paper is understood as the resources needed to generate and manage the technical change through improving the production capabilities and incremental adaptation of technology (Bell \& Pavitt, 1995).

There are three key kinds of capability: technological (acquire, use, adapt, improve and create new technology), innovation and absorption (identify, assimilate and exploit new knowledge). As these capabilities have common elements they are generally studied together, because there is a relationship of containment between them. That is to say, the capability for absorption is vital for the capability of innovation and subsequently for technological capability (Lugones, Gutti \& Le Clech, 2007). Therefore, talking about technological capabilities (Lugones, Gutti \& Le Clech, 2007) implies that the capabilities of innovation and absorption are already considered.

According to Lall (1992), technological capabilities are categorized by their level of complexity in basic, intermediate and advanced; additionally, they sustain that the level of technological capabilities depends on three principle functions: investment, production and networking. Investment capabilities are skills that can allow for the detection and acquisition of technology in order to create new products and services; production capabilities are skills that permit using, adapting, improving or innovating the available technology to create new products and services; production capabilities are skills that allow us to use, adapt, improve or innovate the available technology and that guarantees the maximum operative efficiency; and, the networking capabilities are skills that the company has to use the information that it receives from the exterior with the objective to advance its knowledge.

The level of technological capacity that a company reaches is unequal in its technical functions because companies tend to develop one function more than the other, given the demands of each industry; as such, each company maintains a rhythm of accumulation of technological capacities that are very distinct and yet within the same company, the accumulation is discontinuous at different periods of time (Dutrénit et al., 2003).

Contrary to Lall (1992), Garcia and Navas (2007) propose a typology of technological capabilities as a function of the evolution of the technology of the industry (exploration and exploitation) and of the evolutionary cycle (exclusivity and non-exclusivity). Specifically, they identify the technological capabilities of exploration such as those abilities "oriented towards the permanent development of the incorporation of new knowledge that assumes the constant redefinition of the current technological trajectory" (183). While technological capabilities of exploitation imply the ability to use the dominant technology of the industry, and depending on the diffusion of the technology in the industry, it is classified as exclusive or non-exclusive.

The majority of studies on technological capacities at the business level has centered on analyzing the impact of the technological capabilities on business performance (Welter, Bosse \& Alvarez, 2013; Tsai, 2004; Schoenecker \& Swanson, 2002; Lee, Lee \& Pennings, 2001). Such is the case of Ju, Zheng, Yong, and Lu (2013) who 
conducted a comparison of the impact of technological capabilities on the patterns of growth and performance of 448 local and foreign companies in China. This study shows substantial differences in the levels of improvement and ROA (Return on Investments). Domínguez and Brown (2004) found a positive correlation between the technological capabilities and performance through the profit margin and labor productivity. On the other hand, Krasnikov and Jayachandran (2008) determined that the technological capabilities improve the performance because it increased product innovation and production efficiency. Only Schoenecker and Swanson (2002) found that technological capabilities do not impact financial performance of companies.

Other works have focused on analyzing the relationship of technological capabilities with knowledge management (Zahra, Neubaum \& Larrañeta, 2007), with the impact of the turbulence of technology and the market (Su, Peng, Shen \& Xiao, 2013), with innovation (Zheng \& Wu, 2010), with branching (entry into new niches) (Kotha, Zheng \& George, 2011) and with the internationalization process (Kuramoto \& Kindl, 2012).

A body of research has focused on describing the technological capabilities of specific sectors and countries. For example, Sánchez, García, Álvarez and Lavín (2013) analyzed the innovation capability of assembly plants in the electronics sector; Rasiah (2009) describes and compares the technological capability of automotive companies between Malaysia and Indonesia; and, Brito, Garambullo and Ferreiro (2014) studied the accumulation of technological capability in the electronics industry in Tijuana, Mexico.

Katz (1986) undertook a study where it was shown that companies from Latin America maintain an active attitude towards technology, manifested in the ability to adapt, improve, and export technology transferred by industrialized countries. From these results, diverse works centered on determining the process of technological capability development (that is to say, how to generate technological capability) based on the study of learning processes, developing taxonomy that shows the accumulation $d$ of technological capabilities (Figueiredo, 2003; Lall, 1992; Bell \& Pavitt, 1995).

Additionally, research has been undertaken that analyzed the cooperation, as a specific element of technological capabilities, and its relation to business performance, finding that cooperation impacts productivity (Belderbos, Carree \& Lokshin, 2004), increases the intensity and commitment of R\&D, increases the probability of developing new products (Becker \& Dietz, 2004; Surroca \& Santamaría, 2007) and helps improve initial performance of recently created businesses (Baum, Clabrese \& Silverman, 2000).

\subsection{Conceptual Framework}

Given the focus of the studies on technological capability, which have centered on analyzing the impact of the capabilities in the business performance and in developing taxonomies specific to determined industries, it is necessary to focus the attention on the factors that accelerate the development of the technological capability of companies, specifically in sectors of great economic relevance such as agroindustry.

Figure 1 shows the conceptual framework researched. Using the Resources-Based View as a base, the analysis of cultural capital, social capital, information technologies, investment in $\mathrm{R} \& \mathrm{D}$ and age are proposed as relevant factors that encourage the development of technological capability at the company level.

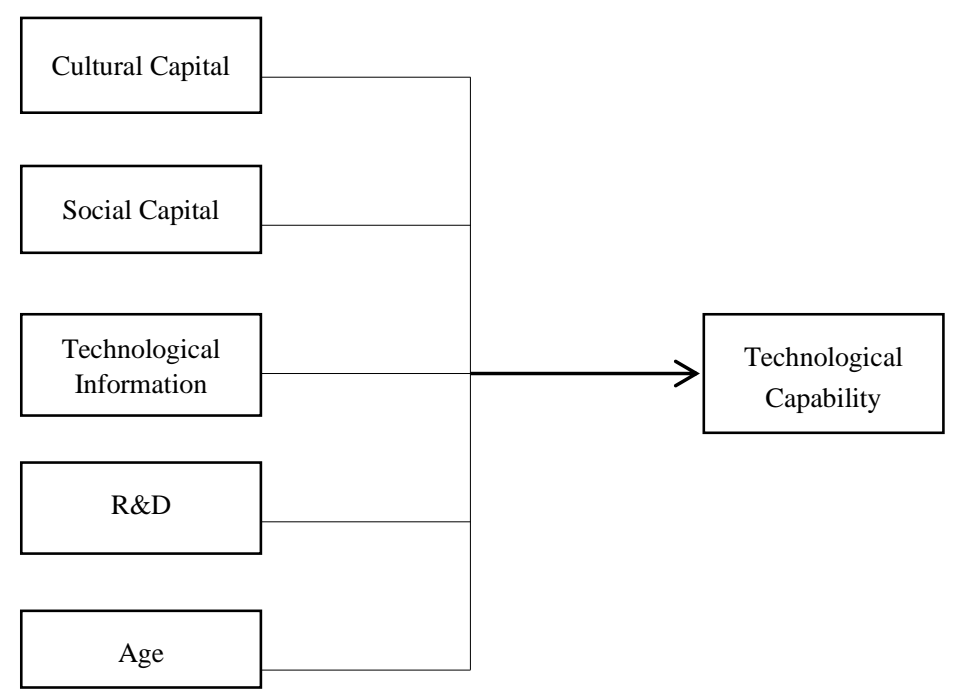

Figure 1. Conceptual framework 
Figure 1 shows the proposed variables for analysis in the explicative technology capability model.

\subsection{Research Hypotheses}

Cultural capital is understood as the set of capabilities of the people who participate in the organization, principally based on their level of education. Cultural capital determines the capacity for analysis, problem solving, acquire new knowledge and to extrapolate from one field of work to another, undertaking distinct tasks and proposing new ideas (Contreras, López \& Molina, 2011). Cultural capital also makes reference to organizational culture, as it is of vital importance for establishing policy and programs that support an innovation culture (Alharthey, Rasli, Yusoff \& Al-Ghazali, 2013). As Bell and Pavitt (1995) mentioned, specialized resources, such as qualified human capital, allows increasing efficiency in the use of technology. Thus, the first hypothesis is as follows:

H1: Cultural capital from personnel positively influences technological capabilities of agri-food industries.

Social capital is another factor that impacts the ways of learning of the businesses and also their technological capabilities. Social capital is "the combination of resources that are bound to the possession of a sustainable network of more or less institutionalized relationships...that are linked to belonging to a group, such as groups of agents that are not endowed with common goods, but are joined by permanent and useful ties" (Bourdieu, 1980; p. 2). Social capital is a process that does not come about spontaneously, but the relationships based on confidence and knowledge of the people. According to Julien (2006), social capital is a lubricant to accelerate interrelations, based on trust, rules, and integrity.

Learning is generated in social relationships of people and their quality depends on the agents involved. Therefore, "in order to establish a relationship of learning there must first exist a social relationship between agents that want to learn and that can teach and that depends on the social concretion of the knowledge or information transfer. In this sense, the transfer of learning is given firstly through social relationships between people" (Contreras, Arroyo \& López, 2012). Through the relationship network that the company establishes with the environment (clients, providers, universities, government, research centers, among others) a favorable environment is created for cooperation in distinct areas, either for sharing information, detect market opportunities, attend to new needs or combine resources between companies that will result in innovation in products or processes. Accordingly, the second hypothesis is as follows:

H2: Social capital positively influences technological capabilities of agri-food companies.

The ability to select and use information in an efficient and effective manner is considered a capability with the potential to generate competitive advantage (Ferguson, Mathur \& Shah, 2005). Specifically, Huber (1990) sustains that technological information allows improving and accelerating the ability for learning and for acquiring knowledge, being fundamental for the development of technological capabilities. Technological information are tools that allow: a) concentrate and administer the information generated, b) share information quickly, c) improve operational process and product management, and d) codify the knowledge base. Technological information also allows better planning and coordination of internal company relationships (Pigni, Ravarini \& Saglietto, 2010), which is where the necessary knowledge is generated to develop technical improvements in processes and products. Dewett and Jones (2001) found that technological information has positive effects on organizational innovation because it facilitates the process of collaboration between workers. These observations suggest the following hypothesis:

H3: The use of technological information positively influences the technological capabilities of agri-food companies.

The importance that the company places on continually increasing its technological capacity determines the financial and human resources that are directed towards this objective. Without those resources, an organization will find it difficult to generate new technology. Diverse authors have found a positive relationship between investment in R\&D and good company performance (Geroski \& Machin, 2013; Coad \& Roa, 2008; Yasuda, 2005; Cooper \& Kleinschmidt, 1996; Chan, Martin \& Kesinger, 1990). Nevertheless, other researchers (Jaruzelski, Dehoff \& Bordia, 2005) have obtained ambiguous results as a function of the temporal period of analysis, of the industry and the country. Subsequently, it is important to evaluate the impact of R\&D on the development of technological capabilities in the agri-food industry. Thus, the hypothesis is as follows:

H4: The investment in research and development positively influences the technological capabilities of agri-food companies.

Experiences in agribusiness are an important factor for the accumulation of technological skills that with time develop and improve their skills, which allows them to operate most efficiently. According to Whitfield (2012), 
lack of experience in an industry puts obstacles between the ability to identify key factors for success, using technology to the max, reaching high levels of efficiency, implementing production practices with international standards, identifying the tendencies of the consumer as much as competitors. For this, businesses with more time on the market possess a greater body of accumulated knowledge that is the basis for generating technological capabilities. Hence, the following hypothesis is:

H5: Age positively influences the technological capacity of agri-food businesses.

\section{Method}

\subsection{Research Methodology}

The focus of the research is quantitative, through data collection and analysis the stated hypotheses were tested, and the factors that determine technological capacity of an organization were determined. This is an explicative research.

A total of 71 companies from the manufacturing sector of the agri-food industry in the Laja-Bajío (Note 2) region were interviewed. The companies had the following characteristics: $26 \%$ were micro, $33 \%$ small, $25 \%$ medium and $16 \%$ large. The majority of the companies interviewed had more than 10 years on the market (87\%).

The National Chamber of the Transformation Industry (CANACINTRA) in the city of Celaya, Guanajuato, Mexico, through the Knowledge Consortium (Consorcio del Conocimiento) (Note 3), provided a directory of approximately 200 companies in the agri-food industry. From this directory, the first contact with the companies was made via telephone, by email and through visits to their work sites with the objective of concerting appointments to apply the research instrument. The survey was applied in person or by phone during 2013. The subjects of the study were the owners of the companies, general managers, and personnel of the companies' middle-mana3gement.

A multiple regression analysis was applied in order to determine the variables that impact technological capability in the agri-food sector companies, using the following model:

\subsection{Measurement of Variables}

$$
T C=\beta_{1} C U L+\beta_{2} S O C+\beta_{3} I T+\beta_{4} I N V+\beta_{5} A G E+\beta_{6} S I Z+\varepsilon
$$

Taking as a base the proposal of Lugones et al. (2007), technological capability was evaluated on the basis of three factors: 1) level of automation of the main production process, 2) technological position compared to the competition, and 3) number of prototypes and patents registered o in process of registration. Based on said technological capability criteria, it is classified as advanced, intermediate and basic (Lall, 1992). Evaluating the technological capabilities implies not only having improved skills in order to use technology more efficiently, but it implies incorporating changes in a systematic way for which the evaluation of technological capabilities should include technology acquisition, but above all technical change, evaluated through patents.

Table 1 shows the measurements of the cultural capital, social capital, incorporation of technological information, investment in $\mathrm{R} \& \mathrm{D}$, age, and size variables.

Table 1. Measurement of variables

\begin{tabular}{|c|c|c|c|}
\hline Variables & Code & Components & Definition \\
\hline \multirow[t]{3}{*}{$\begin{array}{l}\text { Technological } \\
\text { Capability }\end{array}$} & $\mathrm{TC}$ & Automation & $\begin{array}{l}\text { Level of automated and computerized tool use in the principal } \\
\text { production process. }\end{array}$ \\
\hline & & Technological position & Level of technology in relation to principal competitors. \\
\hline & & Prototypes \& Patents & Level of involvement in intellectual property activities. \\
\hline \multirow[t]{3}{*}{ Cultural Capital } & CUL & $\begin{array}{l}\text { Managerial educational level } \\
\text { (EDU) }\end{array}$ & $\begin{array}{l}\text { Level of knowledge that a person acquires through a formal } \\
\text { education. }\end{array}$ \\
\hline & & Staff training (TRA) & Process of training to develop skills that improve performance. \\
\hline & & Incentives (INC) & $\begin{array}{l}\text { Benefits given in order to implement improvements in } \\
\text { processes, equipment, products, creation of new products or } \\
\text { proposing viable projects for improvement. }\end{array}$ \\
\hline
\end{tabular}




\begin{tabular}{|c|c|c|c|}
\hline \multirow[t]{3}{*}{ Social Capital } & SOC & $\begin{array}{l}\text { Cooperation with suppliers } \\
(\mathrm{COS})\end{array}$ & $\begin{array}{l}\text { Links developed with suppliers in order to achieve long-term } \\
\text { mutual benefit. }\end{array}$ \\
\hline & & Cooperation with clients (COC) & $\begin{array}{l}\text { Links developed with the clients in order to achieve mutual } \\
\text { benefit. }\end{array}$ \\
\hline & & $\begin{array}{l}\text { Cooperation with Universities } \\
(\mathrm{COU})\end{array}$ & $\begin{array}{l}\text { Links developed with universities or research centers to } \\
\text { achieve mutual benefit. }\end{array}$ \\
\hline $\begin{array}{l}\text { Incorporation of } \\
\text { technological } \\
\text { information }\end{array}$ & IT & $\begin{array}{l}\text { Use of technological } \\
\text { information (IT) }\end{array}$ & $\begin{array}{l}\text { Incorporation of Information Communication Technologies in } \\
\text { the management of production. }\end{array}$ \\
\hline Investment in $\mathrm{R} \& \mathrm{D}$ & $\mathrm{R} \& \mathrm{D}$ & $\begin{array}{l}\text { Research \& Development } \\
(\mathrm{R} \& D)\end{array}$ & Budget set aside for research and investigation in technology. \\
\hline Age of the company & AGE & Years on the market (AGE) & How long the Company has been on the market. \\
\hline Size of the company & SIZ & Number of employees (SIZ) & Total number of employees that work for the organization. \\
\hline
\end{tabular}

Table 1 shows the components and definitions of the variables.

\section{Results}

The principal economic activities that the companies develop in the agri-food business are: elaboration animal feed; grinding grains and oleic seeds; elaboration of sugar, chocolates, candy, and other similar products; preservation of fruits, vegetables and stews; elaboration of milk products, slaughtering, packing and processing meat from livestock and birds; the preparation and packaging of fish and seafood; and, the elaboration of bread products and tortillas (INEGI, 2007).

Regarding the technological capacity of the companies, data analysis shows that $32 \%$ of the companies count on a high level of automation in their principal productive process, $60 \%$ possess a medium level $(50 \%$ mechanical machinery and/or automated) and $7 \%$ use manual tools in their transformation process. In terms of technological position of the market, a little more than a third of the companies (37\%) thought they had better technology in their processes in relation to competitors, $42 \%$ think that they have similar technology to competitors and only $21 \%$ express being at a technological disadvantage in comparison with their competitors. Only $21 \%$ have registered patents, $20 \%$ are in the process of registering patents and $53 \%$ have developed prototypes. In summary, technological capacity is basic in $27 \%$ of companies, intermediate in $58 \%$ and advanced in $15 \%$.

In terms of cultural capital, evaluated by the educational level of the manager, it should be highlighted that $72 \%$ of companies are directed by personnel with bachelor's degrees and only 13\% with technical or other lower educational level. More than half of the companies (between 52\% and 63\%) train their workers in machine management, quality and continuous improvement in processes and products, work organization, security and hygiene, teamwork and formal education. Around $70 \%$ of companies offer incentives to personnel so that they can improve processes, equipment, and/or products, in order to create new products or to propose new ways to enhance performance.

The main collaboration that companies have with suppliers is by contracts of post-sale technological assistance (72\%). Only a quarter transfer technology with their suppliers, collaborate with them in order to implement technological development or design collaborative strategies. In relation to the collaboration with clients, the majority of the companies did linking activities, with current or potential clients. Of the sample, $90 \%$ of companies formed networks to understand their principle needs, $84 \%$ to implement product and process improvements, $81 \%$ for technological development, $75 \%$ to transfer technology to clients, and $77 \%$ to share information and to design collaborative strategies. The activities in collaboration with universities or research centers were less frequent, where only $60 \%$ of companies took part; however, of those, $73 \%$ maintain strong links.

The use of technological information is low, and only $25 \%$ of the companies use it for production management. A such, the results show a little more than half of the companies setting aside part of the budget for continuous improvement activities, research and development. Only a quarter specified the percentage of sales that are set-aside for R\&D.

In relation to the age of the company, 13\% had been on the market for less than 10 years, $37 \%$ between 11 and 37 years and, half of the companies have been competing for more than 20 years. 
Table 2. Correlation matrix

\begin{tabular}{|c|c|c|c|c|c|c|c|c|c|c|c|}
\hline & EDU & TRA & INC & COS & $\mathrm{COC}$ & $\mathrm{COU}$ & IT & $R \& D$ & SIZ & AGE & TC \\
\hline EDU & 1 & & & & & & & & & & \\
\hline TRA & $.485^{* * *}$ & 1 & & & & & & & & & \\
\hline INC & $.381^{* *}$ & $.411^{* *}$ & 1 & & & & & & & & \\
\hline $\mathrm{COS}$ & $.477 * *$ & $.370 * *$ & $.483^{* *}$ & 1 & & & & & & & \\
\hline $\mathrm{COC}$ & .200 & $.337 * *$ & $.459 * *$ & $.411 * *$ & 1 & & & & & & \\
\hline $\mathrm{COU}$ & -.022 & .280 & $.438^{*}$ & $.318 * *$ & $.330^{*}$ & 1 & & & & & \\
\hline IT & .184 & -.001 & -.093 & .067 & $-.245^{*}$ & -.077 & 1 & & & & \\
\hline$R \& D$ & $.482 * *$ & .164 & -.009 & $.283^{*}$ & -.139 & -.017 & $.494 * *$ & 1 & & & \\
\hline SIZ & $.650 * *$ & $.320 * *$ & .168 & $.458^{* *}$ & .092 & -.080 & $.387 * *$ & $.595^{* *}$ & 1 & & \\
\hline AGE & $.336^{* * *}$ & .102 & .058 & $.278^{*}$ & .125 & -.096 & .146 & -.213 &, $498 * *$ & 1 & \\
\hline $\mathrm{TC}$ & $.570 * *$ & $.472 * *$ & .236 & $.588 * *$ & $.292 *$ & .078 & .169 & $.544 * *$ & $.658^{* * *}$ & $.444 * *$ & 1 \\
\hline
\end{tabular}

**The correlation is significant to the 0.01 level. *The correlation is significant to the 0.05 level. Table 2 shows the indices of correlation between independent and dependent variables.

As far as the correlation indices are concerned, Table 2 shows that the relationship between independent variables are not so high so they should not distort the statistical meaning and invalidate the model. The technological capabilities variable has a medium positive and significant relationship with educational level, training, and cooperation with suppliers, investment in $\mathrm{R} \& \mathrm{D}$, size, and age of the company. Cooperation with clients was found to have a significant relationship with technological capabilities, but it is a weak relationship. Incentives and cooperation with universities is not related to the technological capability of the company.

Table 3. Multiple regression analysis

\begin{tabular}{|c|c|c|}
\hline Variables & Model 1 & Model 2 \\
\hline Educational Level of Management (EDU) & -.088 & \\
\hline Employee Training (TRA) & .022 & \\
\hline Incentives (INC) & -.077 & \\
\hline Cooperation with Providers (COS) & $.203 * *$ & \\
\hline Cooperation with clients (COC) & $.129 * *$ & \\
\hline Cooperation with universities (COU) & -.035 & \\
\hline Cultural capital & & .087 \\
\hline Social capital & & $.174 * *$ \\
\hline Incorporation of ICT (IT) & -.163 & -.114 \\
\hline Investment in $R \& D(R \& D)$ & $.426^{* * *}$ & $.388 * * *$ \\
\hline Age (AGE) & .008 & $.010^{* * *}$ \\
\hline Size (SIZ) & .000 & $.000^{*}$ \\
\hline Constant & $1.245^{* * *}$ & $1.754^{*}$ \\
\hline $\mathrm{F}$ & $7.222 * * *$ & $14.787 * * *$ \\
\hline Prob $>$ F & .000 & .000 \\
\hline $\mathrm{R}^{2}$ adjusted & .60 & .57 \\
\hline Breush- Pagan & .05 & .51 \\
\hline Prob $>2$ & .8273 & .4769 \\
\hline Ramsey Test & .35 & .09 \\
\hline Prob $>2$ & .8273 & .9663 \\
\hline
\end{tabular}

*** Significance to the $1 \%$ level; ** Significance to the $5 \%$ level; *significance to the $10 \%$ level. This table presents the regression results, principally showing the coefficients of the variables, the F statistic, the adjusted R square value, the Breush-Pagan and the Ramsey tests. 
Table 3 represents two models. In the first, the components of the social capital and cultural capital variables are analyzed in a disaggregate way. The results show that $60 \%$ of the variation in the technological capabilities may be explained by the model variables 1 . Cooperation with suppliers, clients, and R\&D investment all have positive and significant correlations $(\mathrm{p}<0.05)$. The rest of the variables had no significant relationships. In the second model, a regression with the social and cultural capital variables explains the $57 \%$ of the variation of the technological capabilities. In this analysis, the social capital, investment in R\&D, age and size show positive and significant coefficients $(\mathrm{p}<.10)$

The Breush-Pagan test was applied to detect heteroscedasticity, given that it is common in cross-sectional data. There are problems of heteroscedasticity. The Ramsey test is used to detect omitted variables, which supports the results obtained with the applied regression. The null hypothesis states that the model has not omitted any variables. At a significance level of $10 \%$, it is found that it is not necessary to include more independent variables in the model. Model 2 continues to have problems of heteroscedasticity, but this is lower in relation the previous model. It also passes the Ramsey test at $10 \%$ significance.

\section{Discussion}

This study seeks to identify the internal factors that influence the development of technological capabilities in the agri-food industry. In the results of both models, cultural capital does not exert any influence on the technological capabilities of the agri-food companies, and therefore hypothesis 1 is not accepted. Even though the educational level, training and incentive schemes are important elements that allow us to obtain and improve the body of knowledge and skills of the personnel in order to apply them to daily functions, they are not characteristically distinctive between companies of the sector, as they show high levels in their descriptive statistics.

Social capital turns out to be the internal factor that has the greatest influence on driving technological capabilities, showing that technological progress is generated through the interaction between users and technology suppliers when they develop the best proposals for the users, as such generating a dynamic of continuous adaptation to technology. In the same way, clients play a major role in the modifying, design and construction processes of greatest value. The above is congruent with Lall (1992) and Bell and Pavitt (1995) in relation to the dependence of technological capabilities, not only as an investment that the company makes, but also of their level of linking with external actors, which are those that support the learning process. According to the above, the second hypothesis is maintained.

Cooperation with suppliers and clients has a greater relevance than cooperation with universities, according to the results of the first model. The statistics found a low level of networking with universities. Regarding the above, there are limitations such as the lack of trust, reluctance to share confidential company information, the level of commitment of the universities, and formalities in the accomplishment of goals, delivery targets and service continuity (López, López \& Molina, 2013). On the other hand, cooperation with universities may acquire greater relevance when the companies achieve a higher level of technological capabilities, as they may not be attractive partners for universities to collaborate with until that point. It should be pointed out that the companies recognize the benefits of collaborating with universities, as those that do maintain strong and active networks.

Regarding technological information, hypothesis 3 is rejected, as it did not result significant in either of the two models. Although the use of technological information does not help to explain the development of technological capabilities, it is important to consider that the use of technological information may support those capabilities in an indirect way that facilitates the management of information and the codification of knowledge. As such, only a quarter of the companies use technological information, being principally the larger and more economically solvent companies that are able to invest in it.

Investment in R\&D is a factor that helps to explain the level of technological capabilities; therefore, hypothesis 4 is maintained. R\&D allows the company to take advantage of knowledge, skills and accumulated experience of the organization in order to generate better techniques in the products and processes, in such a way as generate competitive advantage. Although, the designation of resources to R\&D activities will depend on the financial capability and the company culture, it is essential that this activity is present in organizations, as it supports the development of technological capabilities. Of course, that the only allocation of resources to R\&D does not assures the development of patents or prototypes, as there are other factors that should be present in order to generate them.

The results show that age positively influences the technological capacity of companies. Therefore, hypothesis 5 is maintained. Young businesses are not as efficient as mature companies because they have not yet learned from experience and from the development of abilities to improve their production techniques and to operate more 
efficiently. Therefore, with time they have developed the necessary skills to acquire and maximally use the knowledge that they possess, which are reflected in the greater capability to generate technical change. Finally, and in relation to the size of the company, it was found that larger companies possess greater levels of technological capacities.

\section{Conclusions}

The objective of this study was to analyze the internal factors that influence the development of technological capabilities in agri-food companies. The findings show that social capital, investment in R\&D, age, and size of the company are all variables that explain the level of technological capability of the agri-food sector. The educational level of management and training of personnel, even though it doesn't help to explain the level of technological capabilities, there is a significant positive relationship with those capabilities.

The findings have diverse implications for academics, practitioners, and government. The academic implications of this study advance knowledge with respect to technological capabilities. First, the study supports the existing knowledge on technological capabilities in the agri-food industry in developing countries, through an explanatory model of technological capabilities. Second, this model includes the analysis of social capital as a determinant variable in the study of the technological capabilities, and that few studies have considered as relevant. Third, the results show the pertinence for propose multivariate models that generate a more complete vision of the explanatory factors of the development of technological capabilities.

In relation to practitioners, they should consider investing more heavily in $R \& D$ in order to use the knowledge generated in the organization and transform it into innovations and improvements in products and processes. In addition, companies should be aware of the benefits that cooperation with suppliers and clients bring to implement new collaborative strategies and to realize technological developments. Once the company has reached medium levels of technological capabilities, it should try to generate collaborations with universities and research centers, where a higher technological level is necessary in order to obtain the clear advantages of networking.

For the governmental sector, it is necessary to develop public policy that support the development of technological capabilities focused on financing innovative projects, fiscal incentives for the acquisition and development of technology, training programs and proposals for new support frameworks for external networking, specifically for the agri-food industry.

Future research should concentrate on studying those factors that impact on technological capabilities, increasing the size of the sample, applying comparisons between states and industries, and above all, incorporating the modified variables such as business strategy and the entrepreneurial orientation of the company.

\section{Acknowledgments}

We thank to the Direction of Support for Research and the Graduate School (DAIP) of the University of Guanajuato for the support in the translation of this research work.

\section{References}

Alharthey, B., Rasli, A., Yusoff, R., \& Al-Ghazali, B. (2013). Impact of Innovation Culture on Human Resources Management Practices. International Journal of Academic Research, 5(3), 60-63.

Amit, R., \& Schoemaker, P. (1993). Strategic Assets and Organizational Rent. Strategic Management Journal, 14, 33-46. http://dx.doi.org/10.1002/smj.4250140105

Barney, J. (1991). Firm Resource and Sustained Competitive Advantage. Journal of Management, 17(1), 99-120. http://dx.doi.org/10.1177/014920639101700108

Baum, J., Calabrese, T., \& Silverman, B. (2000). Dont go it Alone: Alliance network Composition and Startups' performance in Canadian Biotechnology. Strategic Management Journal, 21, 267-294. http://dx.doi.org/10.1002/(SICI)1097-0266(200003)21:3\%3C267::AID-SMJ89\%3E3.0.CO;2-8

Becker, W., \& Dietz, J. (2004). R\&D Cooperation and innovation activities of firms- evidence for the German manufacturing industry. Research Policy, 33, 209-223. http://dx.doi.org/10.1016/j.respol.2003.07.003

Belderbos, R., Carree, M., \& Lokshin, B. (2004). Cooperative R\&D and firm performance. Research Policy, 33, 1477-1492. http://dx.doi.org/10.1016/j.respol.2004.07.003

Bell, M., \& Pavitt, K. (1995). The Development of Technological Capabilities. In Irfan ul Haque (Ed.), Trade, technology, and International Competitiveness. EDI (Economic Development Institute) DEVELOPMENT STUDIES. The World Bank Washington, DC. 
Bourdieu, P. (1980). El Capital Social. Notas Provisorias. Actas de Investigaciones en Ciencias Sociales, 31.

Brito, J., Garambullo, A., \& Ferreiro, V. (2014). Aprendizaje y Acumulación de Capacidades Tecnológicas en la Industria Electrónica de Tijuana. Revista Global de Negocios, 2(2), 57-68.

Chan, S., Martin, J., \& Kensinger, J. (1990), Corporate Research and Development Expenditures and Share Value. Journal of Financial Economics, 26(2), 255-276. http://dx.doi.org/10.1016/0304-405X(90)90005-K

Coad, A., \& Rao, R. (2008), Innovation and firm growth in high tech sectors: A quantile regression approach. Research Policy, 37(4), 633-648. http://dx.doi.org/10.1016/j.respol.2008.01.003

Contreras, R., Arroyo, B., \& López, A. (2012). Formas de Aprendizaje en las Mipymes. Una perspectiva Socio-cultural. México: Universidad de Guanajuato.

Contreras, R., López, A., \& Molina, R. (2011). Emprendimiento: dimensiones sociales y culturales en las Mipymes. México: Ed. Pearson.

Cooper, R., \& Kleinschmidt, E. (2007). Winning Businesses in Product Development: The Critical Success Factors. Research Technology Management, May-Jun.

Cuero, Y., Un Nabi, M., \& Dornberger, U. (2012). Technological Capability Improvement as Result of the Entrepreneur's Search for innovation in the SMEs in Colombia. Journal of Marketing Development \& Competitiveness, 6(4), 1-16.

Dewett, T., \& Jones, G. (2001). The Role of Information Technology in the Organization: A Review, Model, and Assessment. Journal of Management, 27, 313-346. http://dx.doi.org/10.1177/014920630102700306

Domínguez, L., \& Brown, F. (2004). Medición de las Capacidades Tecnológicas de la Industria Mexicana. Revista de la Cepal, 83, 135-151.

Dosi, G. (1988). Sources, Procedures, and Microeconomic Effects of Innovation. Journal of Economic Literature, XXVI(september), 1120-1171.

Dutrénit, G., Vera-Cruz, A., \& Arias, A. (2003). Diferencias en el Perfil de Acumulación de Capacidades Tecnológicas en tres Empresas Mexicanas. El Trimestre Económico, 70(277), 109-165.

Ferguson, G., Mathur, S., \& Shah, B. (2005). Evolving from information to insight. MIT Sloan Management Review, 46(2), 51-58.

Figueiredo, P. (2002). Learning Processes features and Technological Capability-Accumulation: Explaining Inter-Firm Differences. Technovation, 22, 685-698. http://dx.doi.org/10.1016/S0166-4972(01)00068-2

Figueiredo, P. (2003). Learning, Capability Accumulation and Firms Differences: Evidence from latecomer Steel. Industrial and Corporate Change, 12(3), 607-643. http://dx.doi.org/10.1093/icc/12.3.607

García, F., \& Navas, J. (2007). Las capacidades tecnológicas y los resultados empresariales. Un estudio empírico en el sector biotecnológico español. Cuadernos de Economía y Dirección de la Empresa, 32, 177-210.

Geroski, P., \& Machin, S. (2013), Think Again. Do innovating firms outperform non innovators? Business Strategy Review, 24(2), 82-86. http://dx.doi.org/10.1111/j.1467-8616.2013.00959.x

Grant, R. (1991). The Resource-Based Theory of Competitive Advantage: Implications for Strategy Formulation. California Management Review, 33(3), 114-135. http://dx.doi.org/10.2307/41166664

Hitt, M., \& Ireland, R. (2000). Technological Learning, Knowledge Management, Firm Growth and Performance: An Introductory Essay. Journal of Engineering \& Technology Management, 17(3/4), 231-246. http://dx.doi.org/10.1016/S0923-4748(00)00024-2

Hobday, M., \& Rush, H. (2007). Upgrading the Technological Capabilities of Foreign Transnational Subsidiaries in Developing Countries: The Case of Electronics in Thailand. Research Policy, 36, 1335-1356. http://dx.doi.org/10.1016/j.respol.2007.05.004

Huber, (1990). A Theory of the Effects of Advanced Information Technologies on Organizational Design, Intelligence, and Decision Making. Academy of Management Review, 15(1), 47-71. http://dx.doi.org/10.2307/258105

INEGI. (2007). Sistema de Clasificación de América del Norte.

INEGI. (2009). Censos Económicos.

Jaruzelski, B., Dehoff, K., \& Bordia, R. (2005). Money Isn’t Everything. Strategy+Business Magazine, 41. Retrieved from http://www.strategy-business.com/article/05406 
Ju, M., Zheng, K., Yong, G., \& Lu, J. (2013). Technologival Capability Growth and Performance Outcome: Foreign Versus Local Firms in China. Journal of International Marketing, 21(2), 1-16. http://dx.doi.org/10.1509/jim.12.0171

Julien, P. (2006). Emprendimiento Regional y Economía del Conocimiento; una Metáfora de las Novelas Policiacas. Colombia: Ed. Pontificia Universidad Javeriana.

Katz, J. (1986). Desarrollo y crisis de la capacidad tecnológica latinoamericana. El caso de la industria metalmecánica. Buenos Aires: CEPAL.

Kim, L. (1997). From Imitation to Innovation. The Dynamics of Korea's Technological Learning. Boston MA: Harvard Business School Press. Retrieved May 20, 2008, from http://www.oei.es/memoriasctsi/mesa14/m14p01.pdf

Kotha, R., Zheng, Y., \& George, G. (2011). Entry Into New Niches: The Effects of Firm Age and the Expansion of Technological Capabilities on Innovative Output and Impact. Strategic Management Journal, 32, 10111024. http://dx.doi.org/10.1002/smj.915

Krasnikov, A., \& Jayachandran, S. (2008). The Relative Impact of Marketing. Research-and-Development, and Operations Capabilities on Firm Performance. Journal of Marketing, 72, 1-11.

Kuramoto, R., \& Kindl, S. (2012). Internationalization Process and Technological Capability Trajectory of Iguacu. Journal of Technology Management \& Innovation, 7(2), 117-129. http://dx.doi.org/10.4067/S0718-27242012000200010

Lall. S. (1992). Technological capabilities and industrialisation. World Development, 20(2), 165-86. http://dx.doi.org/10.1016/0305-750X(92)90097-F

Lee, C., Lee, K., \& Pennings, J. (2001). Internal Capabilities, External Networks, and Performance: A Study on technology-Based Ventures. Strategic Management Journal, 22, 615-640. http://dx.doi.org/10.1002/smj.181

López, A., López, C., \& Molina, R. (2013). Capacidades Tecnológicas y de Innovación de la Industria Agroalimentaria de la Región Laja-Bajío, Conference Preceedings ACACIA 2013.

Lugones, G., Gutti, P., \& Le Clech, N. (2007). Indicadores de Capacidades Tecnológicas en América Latina. CEPAL- Serie Estudios y Perspectivas, (89). 1-68.

Martín, M., \& Estrada, S. (2011). Desarrollo Agroindustrial en México, In A propósito del Sistema Sectorial de Innovación en la Agroindustria Mexicana. México: Ed. Universidad de Guanajuato y Universidad Michoacana de San Nicolás de Hidalgo.

Mendes, M., \& DuBois, F. (2012). Technological Capabilities of Brazilian Shipbuilding Suppliers. Journal of Technology Management \& Innovation, 7(2), 39-50.

Pigni, F., Ravarini, A., \& Saglietto, L. (2010). An Explorative Analysis of the Effects of Information and Communication Technologies and Inter-Organizational Relationships on Supply Chain Management Systems. Supply Chain Forum: International Journal, 11(4), 36-48.

Prahalad, C., \& Hamel, G. (1990). The Core Competence of the Corporation. Harvard Business Review, mayo-junio, 79-91.

Rasiah, R. (2009). Technological Capabilities of Automotive Firms in Indonesia and Malaysia. Asian Economic Paper, 8(1), 151-169.

Rumelt, R. (1984). Toward a Strategic Theory of the Firm. Competitive Strategic Management (pp. 556-570). New Jersey: Prentice-Hall. Englewood Cliffs.

Sánchez, M., García, F., Álvarez, M., \& Lavín, J. (2013). Technological Capabilities: Construction and Evaluation of the Delphi case in Tamaulipas (México). Revista de Estudios en Contaduría, Administración e Informática, 2(4), 54-75.

Schoenecker, T., \& Swanson, L. (2002). Indicators of Firm Technological Capability: Validity and Performance Implications. IEEE Transactions on Engineering Management, 49(1), 36-44. http://dx.doi.org/10.1109/17.985746

Su, Z., Peng, J., Shen, H., \& Xiao, T. (2013). Technological Capability, Marketing Capability, and Firm Performance in Turbulent Conditions. Management and Organization Review, 9(1), 115-137.

Surroca, J., \& Santamaría, L. (2007). La Cooperación Tecnológica como determinante de los resultados 
empresariales. Cuadernos de Economía y Dirección de la Empresa, 33, 31-62.

Tsai, K. (2004). The Impact of Technological capability on Firm Performance in Taiwan's electronics Industry. Journal of High Technology Management Research, 15(2), 183-195. http://dx.doi.org/10.1016/j.hitech.2004.03.002

Welter, C., Bosse, D., \& Alvarez, S. (2013). The Interaction Between managerial and Technological Capabilities as a Determinant of Company Performance: An Empirical Study of Biotech Firms. International Journal of Management, 30(1), 272-284.

Whitfield, L. (2012). Developing Technological Capabilities in Agro-Industry: Ghana's Experience with Fresh Pineapple Exports. Journal of Development Studies, 48(3), 308-321. http://dx.doi.org/10.1080/00220388.2011.635198

World Economic Forum. (2013). The Global Competitiveness Report 2012-2013.

Yasuda, T. (2005). Firm growth, size, age and behavior in Japanese manufacturing. Small Business Economics, 24(1), 1-15. http://dx.doi.org/10.1007/s11187-005-7568-y

Zahra, S., Neubaum, D., \& Larrañeta, B. (2007). Knowledge Sharing and Technological Capabilities: The Moderating role of Family Involvement. Journal of Business Research, 60, 1070-1079. http://dx.doi.org/10.1016/j.jbusres.2006.12.014

Zheng, K., \& Wu, F. (2010). Technological Capability, Strategic Flexibility, and Product Innovation. Strategic Management Journal, 31, 547-561.

\section{Notes}

Note 1. The strength of institutions, infrastructure, macroeconomic stability, the efficiency of the market of goods, the financial market, and the labor market are factors that affect the technological capabilities of companies (World Economic Forum, 2013).

Note 2. The Laja-Bajío region comprises of the municipalities of Apaseo el Alto, Apaseo el Grande, Celaya, Comonfort, Cortazar, Jaral del Progreso, Santa Cruz de Juventino Rosas, Tarimoro, and Villagrán.

Note 3. Association in charge of generating a culture of innovation in companies through networking between companies, research centers, and universities, through the elaboration of innovation and technology development projects.

\section{Appendix}

This appendix presents the study's measures for technological capabilities, cultural capital, social capital, R\&S, technological information and permanence in the market.

Section 1. Technological capabilities

a. Characteristics of the main productive process.

b. Technological position of your company in relation to the competition (ahead of the competition, like most of the companies in the sector, more efficient technology).

c. Intellectual property actions (prototypes, registration of patents, patents registered).

Section 2. Cultural Capital

a. School level of managers and production manager.

b. Training frequency: 1) modern equipment; 2) learn new ways of organizing work; 3) increase the quality and continuous improvement of processes and products; 4) security and hygiene; 5) teamwork; 6) formal education.

c. Type of incentives that the company uses.

Section 3. Social Capital

a. Frequency of the activities of cooperation with suppliers: 1) Technological assistance after-sales contracts; 2) transfer of technology to enhance efficiency, quality and local supply; 3) collaboration for technological development; 4) share information to develop collaborative strategies.

b. Frequency of the activities of cooperation with current or potential clients: 1) meet main needs of the 
customer; 2) participation of clients in the improvement of products and processes; 3) collaboration with clients on technological developments; 4) technology transfer to clients; 5) share information to develop collaborative strategies.

c. Frequency of the activities of cooperation with Universities and research centers.

Section 4. Other variables

a. Use of technological information for the production management

b. Percentage of sales allocated to activities of continuous improvement, R\&D and innovation.

c. Age of the company

d. Size of the company

\section{Copyrights}

Copyright for this article is retained by the author(s), with first publication rights granted to the journal.

This is an open-access article distributed under the terms and conditions of the Creative Commons Attribution license (http://creativecommons.org/licenses/by/3.0/). 